\title{
Advanced Gas Turbine Systems Research
}

\author{
Quarterly Report \\ April - June 1995
}

July 1995

Work Performed Under Contract No.: DE-FC21-92MC29061

For

U.S. Department of Energy

Office of Fossil Energy

Morgantown Energy Technology Center

Morgantown, West Virginia

By

Clemson University

Clemson, South Carolina 


\section{DISCLAIMER}

This report was prepared as an account of work sponsored by an agency of the United States Government. Neither the United States Government nor any agency thereof, nor any of their employees, makes any warranty, express or implied, or assumes any legal liability or responsibility for the accuracy, completeness, or usefulness of any information, apparatus, product, or process disclosed, or represents that its use would not infringe privately owned rights. Reference herein to any specific commercial product, process, or service by trade name, trademark, manufacturer, or otherwise does not necessarily constitute or imply its endorsement, recommendation, or favoring by the United States Government or any agency thereof. The views and opinions of authors expressed herein do not necessarily state or reflect those of the United States Government or any agency thereof.

This report has been reproduced directly from the best available copy.

Available to DOE and DOE contractors from the Office of Scientific and Technical Information, 175 Oak Ridge Turnpike, Oak Ridge, TN 37831; prices available at (615) 576-8401.

Available to the public from the National Technical Information Service, U.S. Department of Commerce, 5285 Port Royal Road, Springfield, VA 22161; phone orders accepted at (703) 487-4650. 


\title{
Advanced Gas Turbine Systems Research
}

\author{
Quarterly Report \\ April - June 1995
}

Work Performed Under Contract No.: DE-FC21-92MC29061

\author{
For \\ U.S. Department of Energy \\ Office of Fossil Energy \\ Morgantown Energy Technology Center \\ P.O. Box 880 \\ Morgantown, West Virginia 26507-0880
}

\author{
By \\ Clemson University \\ South Carolina Energy Research \& Development Center \\ 386-2 College Avenue \\ Clemson, South Carolina 29634-5180
}

July 1995

DISTRIBUTION OF THIS DOCUIMENT IS UNLRAITED 
Technical Progress Report

Advanced Gas Turbine Systems Research

Cooperative Agreement DE-FC21-92MC29061

April 1, 1995 - June 30, 1995

SUMMARY

Major Accomplishments and Reports issued by AGTSR during this reporting period:

- 12-month (FY95) contract extension for $\$ 4.8 \mathrm{M}$ approved by METC

- IRB proposal review meeting conducted April 5-7, 1995

- AGTSR update briefing presented to METC on May 5, 1995

- 9 new research awards under 95RFP approved by METC on May 9, 1995

- 9 new NEPA's in preparation for FY95 subcontract awards

- 6 AGTSR industrial interns started in June, 1995

- 7 universities submitted letters of endorsement for AGTSR to Congress

- AGTSR Paper Presented at IGTI Turbo-Expo on June 6, 1995

- 93, 94 continuation amendments and 95 proposal negotiations in process

- AGTSR becomes affiliate member of the Gas Turbine Association

- 94 semi-annual progress reports distributed to METC and IRB

- Heat transfer workshop addendum distributed to participants

- Combustion II workshop proceedings distributed to participants

- Plans initiated to co-host FY96 materials workshop with Oak-Ridge

- Dual-fuel research issue coordinated with IRB

- AGTSR's faculty/student outreach consolidated for 23 subcontractors

- AGTSR internship-education paper submitted for review on May 12, 1995

- Telephone debriefings conducted for 95RFP nonwinners

- Site visit to University of MD and DOE-HQ on June 23, 1995

- International gas turbine program idea presented to DOE-METC and HQ

Based on the 95-01 RFP solicitation, nine new research projects have been added to the AGTSR Industry/University Research Consortium. This was the third RFP issued to-date. A total of 32 research efforts are now underway; 11 projects are in combustion, 11 in heat transfer, 5 in aerodynamics, and 5 in materials. For this particular RFP, proposals were reviewed and evaluated not only by the Industry Review Board (IRB) but also by technical experts representing DOD, NASA, and DOE-Oak-Ridge. Since the outcome of this evaluation was considered quite effective by the 
IRB, we will continue this type of collaborative review process for future RFP's.

Another highlight of this reporting period was the addition of AlliedSignal Engine Company as a new AGTSR Industrial Member. The technical point of contact is Dr. David Winstanley. Dave attended the AGTSR Heat Transfer Workshop and participated in the IRB Proposal Review Meeting in April, 1995. AGTSR has also recently completed two outstanding technical workshops. The first heat transfer workshop took place in early March, 1995 at Hilton Head Island and was hosted by Clemson Univerity. AGTSR's second workshop in combustion took place in Indianapolis and was hosted by Purdue University and Allison Engine Company. Tentative plans are already in the works for a materials workshop to take place in Charleston, SC in February, 1996, to be cohosted with DOE-Oak Ridge.

AGTSR initiated their first Industrial Internship program this summer. The IRB selected 6 interns out of 13 applications. One intern is positioned at each of the sponsoring companies. We are excited about this program and hope to expand it next year.

AGTSR subcontractors have voiced strong endorsements for our gas turbine R\&D program and several letters of support have been sent to local congressmen and senators on behalf of ATS and our industry-university research consortium.

In 1993 and 1994, AGTSR received cost-sharing contributions of $\$ 25,000$ from each of the IRB members. TurboPower (United Technologies), Solar Turbines, Allison, Westinghouse and AlliedSignal have paid their 1995 IRB fee. A third invoice was sent to GE --they have now notified us that our invoice has been received and they plan to send their dues payment shortly. The IRB now consists of six U.S. turbine engine manufacturers, with EPRI and GRI continuing to act as utility and industrial gas turbine advisors for AGTSR.

No new universities have joined the AGTSR program during this period. Currently, 78 universities are members of AGTSR, representing 37 states. Saginaw Valley State University has recently expressed interest in joining the program. 
Membership

During this reporting period, no new universities were added as AGTSR Performing Members. Saginaw Valley State University in Michigan has requested information on how to become a Performing Member. Saginaw Valley is a four year institution and offers a bachelor's degree in mechanical engineering. If they join AGTSR, performing membership will be 79 schools, representing 37 states. Other recent members include Polytechnic University in New York, and Northeastern University in Massachusetts.

AlliedSignal Engine Company has been approved as a full IRB member and has already paid their $\$ 25 \mathrm{~K}$ membership fee for FY95.

Parker Hannifin has expressed strong interest in joining AGTSR in FY96. They are interested in Dual-Fuel issues which will be a likely research topic in future RFP's. Parker has an active interest in our program and attended our Combustion II Workshop in Indianapolis. Dresser Rand and BFGoodrich are still interested and there is a good chance they will join AGTSR next year.

An IRB invitation was recently sent to Sermatech (a coatings company). They have not yet responded. Other coating companies (such as Howmet and Praxair Surface Technologies) will be contacted in the future. An IRB Letter of Invitation was also mailed to the R\&D department of the Long Island Lighting Company, who are interested in combined-cycles and advanced, low emission gas turbine combustor concepts. At the IGTI Turbo-Expo in Houston this summer, Florida Power \& Light Company (POC is Dave Stephens, 407-694-4404) approached us to express their interest in the AGTSR consortium and offer their facility as a test bed for new materials, combustor concepts, and performance/diagnostics studies.

\section{3-1994 Subcontract Progress}

AGTSR is close to finishing the amendment packages to continue 22 of the 23 existing projects into follow-on year extensions. The University of Wyoming, initially a one-year effort, was not recommended for renewal by the IRB. This project will terminate this summer with the final report due in September, 1995. The subcontract agreements for the nine new projects approved in FY95 are nearing completion and will be mailed out shortly. The nine new subcontracts should be started by September 1, 1995. Semi-annual progress reports have now been received for the thirteen 1994 subcontracts. The executive summaries of these reports have 
been distributed to respective technical experts and R\&D managers within METC and the IRB. The annual reports for the 1994 awards are due July 31, 1995. For the ten 1993 projects, we are still waiting on two universities to submit their semi-annual progress reports. These two reports are expected to be received shortly. AGTSR expects to mail out all reports by the end of July, 1995. The second annual reports for the 1993 subcontracts are due October 31, 1995.

In order to determine the extent and continuance of IRB interest in the 23 existing projects and the 9 new awards, AGTSR will be requesting the IRB to rank all ongoing research contracts in an interest survey. This contract interest ranking will be completed by the end of August, 1995.

\section{RFP Results}

The AGTSR Industry Review Board (IRB) met on April 5-7, 1995 to recommend new research awards based on RFP 95-01. Many of the proposals and abstracts were reviewed and evaluated beforehand by industry and other technical experts. Fifty-nine proposals were received under this RFP, representing 28 states and 40 institutions. The IRB recommended 9 new projects for funding totaling $3.1 \mathrm{M}$ dollars. Also, during the review, AGTSR received strong endorsement from the IRB for the Workshops, Internships and Undergraduate Fellowship programs. These activities considered "trial" up to this point will become an integral part of AGTSR in the future. On May 5, 1995, Dan Fant gave an update to METC on the AGTSR program and reviewed the IRB recommendations for new awards. On May 9, 1995, METC approved the nine new projects. The technology distribution for the 95RFP is shown below.

$\begin{array}{lcc}\text { TECHNOLOGY } & \text { NO. SUBMITTED } & \text { NO. AWARDED } \\ \text { Combustion } & 21 & 3 \\ \text { Aerodynamics } & 17 & 2 \\ \text { Heat Transfer } & 12 & 3 \\ \text { Materials } & 6 & 1 \\ \text { Advanced Cycles } & 3 & 0\end{array}$


Heat Transfer Workshop

AGTSR's first heat transfer workshop, hosted by Clemson University, took place March 1-3, 1995 at Hilton Head Island, SC. Over 70 people participated at the workshop with a strong attendance from industry and university researchers in the field. Heat transfer experts from NASA-Lewis and Air Force also attended the workshop. Tom Bechtel, the Director of METC, gave the keynote dinner address where he stressed the importance of ATS and urged industry and universities to continually strive to work closer together -- especially at the R\&D level. Some of the key conclusions identified at the workshop addressed the need for coupled aero-cooling optimization methods, doing more fundamental work in disk cooling and cavity flows, closed-loop air-mist cooling concepts and new advanced yet simple methods for internal cooling augmentation, new cooling concepts for the turbine gas path endwall regions, unsteady blade vane passing influence on heat transfer and film-cooling, and the need for software companies to attend AGTSR workshops to better understand the heat transfer modeling issues confronting industry and universities. Heat transfer workshops will probably continue on a bi-annual basis. The Air Force Office of Scientific Research (AFOSR) has mentioned that they are interested in co-sponsoring a heat transfer workshop next summer with AGTSR, as they are supporting several heat transfer projects within their internal flows program. An addendum to the Heat Transfer Proceedings was mailed out in early June, 1995. The addendum included viewgraphs not available when the Proceedings were printed and Summary Notes that were prepared by the moderators of each session. If you would like a full copy of the Heat Transfer Workshop Proceedings, please call Ms. Glenda Black at 803-6562267.

Second Combustion Workshop

The second AGTSR Combustion Workshop was hosted by Purdue University and Allison Engine Company, and took place at Indianapolis, March 27-29, 1995. Over 85 people attended this workshop. An industry panel was assembled to discuss industries problems and concerns in the combustion instability area that required further research to enable lean, premixed combustion under realistic ATS operating conditions. Some of the important research issues highlighted at the workshop were the need for high pressure scaling, the justification of dual-fuel research, the coupling of 
swirl-acoustics influence, and NASA-Lewis' offering of a National Combustor Code by FY99 to industry and universities. AGTSR still plans to have combustion workshops on an annual basis. Several participants recommended AGTSR consider a Gordon-Style conference for next years workshop. Professor Scott Samuelsen has offered to host the Combustion III workshop at UC-Irvine. Additional Combustion II Workshop proceedings are available and may be obtained from Ms. Donna Kelly by calling 803-656-2267.

\section{Materials Workshop in Planning}

An AGTSR materials workshop is tentatively scheduled for February, 1996 in Charleston, SC. This workshop will be co-hosted by AGTSR and DOE-Oak Ridge. A technical organizing committee is being established that consists of DOE, university and industry members to outline the potential topics for the workshop, such as coatings, material degradation and lifetime prediction models, casting/alloy development, ceramics, and new emerging material concepts beneficial to the ATS program. A workshop organization meeting is scheduled for July 18-19, 1995 to discuss details of the technical agenda and review the lab and ongoing ATS materials research at Oak-Ridge.

\section{Industrial Interns Begin this Summer}

The AGTSR Industrial Internship program was highly endorsed by the IRB and will begin for the first time this summer. A total of thirteen applications were received and based on industries review and evaluation, six interns were selected to participate in the eight-week long program. Three interns from UC-Irvine were targeted for Solar Turbines, AlliedSignal, and P\&W. An intern from Carnegie Mellon will go to GECorporate R\&D, another from Central Florida will join Westinghouse Orlando, and an intern from VPI will join Allison Engine Company in Indianapolis. The interns began work near the end of June, 1995 and will be paid a weekly stipend of $\$ 450$ dollars per week. The interns will work on both experimental and computational projects as related to the ATS program. If the program is deemed successful, AGTSR plans to open the Internship to all 78 AGTSR performing member universities in the future. 


\section{AGTSR Presents Paper at the 1995 Turbo-Expo}

Dan Fant and Larry Golan presented their AGTSR paper at the IGTI Turbo-Expo Conference in Houston this summer. The paper was entitled "A Collaborative Venture: The Advanced Gas Turbine Systems Research Program." The paper was well attended in Houston and discussed the objectives and merits of the AGTSR research consortium, progress achieved to date, and future challenges and planned activity. The paper was presented in the session on industry, government, and university gas turbine consortia. The session chair was Milt Davis of Arnold Engineering Development Center and the vice chair was Steve Frankel of Purdue University. If you would like a copy of the paper please call Dan Fant at 803-656-2267.

\section{AGTSR's Faculty/Student Outreach Consolidated}

Based on a recent AGTSR Faculty/Student Inventory Summary, our FY93 and FY94 research subcontracts have placed AGTSR in contact with nearly 200 professors and students nationwide. It is this type of outreach that will keep our land-based gas turbine business competitive in the worldwide market. In addition, AGTSR will continue to grow and impact students, professors and industry as we initiate more research projects and continue to nurture the industrial internship and undergraduate fellowship programs within the AGTSR educational mission. This outreach survey will be updated in FY96.

\section{AGTSR Becomes Active in GTA}

In the Spring of 1995, the newly established Gas Turbine Association (GTA) took over the charter of the American Gas Turbine Manufacturer's Association (AGTMA). The new chairman is Bill Day of United Technologies Turbo Power and the treasurer is Sy Ali of Allison. The executive director and spokesperson for GTA is Jeff Abboud. His telephone number is 703-812-9433. GTA is located on 1600 Wilson Blvd. in Arlington, VA. AGTSR has discussed the consortium with Jeff and has mailed background material, success stories and fact sheets to GTA in support of our industry-university research consortium. The next board meeting is scheduled for August 7, 1995 at the Crystal Gateway Marriot in DC. AGTSR has been invited to participate at this meeting, which will 
include IRB members, DOE-METC and DOE-HQ. SCERDC is an affiliate member of GTA.

\section{Miscellaneous Activity}

AGTSR conducted a one-day site visit at the University of Maryland on June 23, 1995. This visit was done in conjunction with Morgan State University (MSU), who have a companion HBCU subcontract that supports the experimental combustion program at Maryland. The experimental program examines fuel/air mixing and the role of fuel jet penetration and swirl on flame characteristics. The goal is to advance the design of fuel nozzles and combustor geometries for land-based gas turbine combustors. MSU's research program seeks to develop and introduce techniques for simulating combustor operations with a view to more effectively inter-relate combustor design with combustor performance. A half-day was spent reviewing their research progress and plans, touring their experimental combustion facilities, and meeting the graduate students -- several of which are Afro-American. Their combustion lab was impressive and the enthusiasm and number of students involved in the AGTSR-related combustion research was equally impressive. Dan Fant also debriefed the PI's on their latest proposal which was not supported under the 95RFP competition. In the late afternoon, a visit was made to DOE-HQ to meet the new ATS Program Manager, Stan Blazewicz. Dan Fant briefly met with Bill Parks and then reviewed the AGTSR Research Consortium with Stan. Stan seemed happy to be working on the ATS program and was pleased with the overall progress of AGTSR. Dan Fant also left a package with Stan on SCERDC's idea of an International program that takes advantage of gas turbine R\&D in Russia and China in support of ATS. A similar package was also mailed to Curt Nakaishi of DOE-METC. Stan has not yet responded to the idea, but Curt has called us back to let us know that he is interested in certain parts and will coordinate with Chuck Zeh in the next few weeks.

The Dual-Fuel Issue has also been coordinated with the IRB. The majority have responded and have recommended that AGTSR research start to focus on liquid fuel issues in future RFP's. Liquid fuel capability offers some fundamental technical issues on premixing, flashback and coking, which are worthy of investigation.

A detailed description of the AGTSR research consortium was recently included in KEDS -- a national Knowledge Express Database System in support of U.S. industry and technology transfer. KEDS is operated out of Clemson's Center for Applied Technology (CAT). 
AGTSR Letters of Endorsement to Congressmen and Senators have been received from BYU, Georgia Tech, Arkansas, Connecticut, Minnesota, LSU, and UC-Berkeley. Several other PI's have called to say that they believe strongly in the goals of ATS and they plan to send out endorsements letters over the summer. Copies of all letters are being sent to METC for the record. 